\title{
Innovative Method of Utilising Hydrogen Peroxide for Source Water Management of Cyanobacteria
}

Jianyin huang ( $\sim$ leslie.huang@unisa.edu.au )

University of South Australia https://orcid.org/0000-0003-1584-9341

Maximus Ghaly

University of South Australia

Peter Hobson

South Australian Water Corporation

Christopher W.K. Chow

University of South Australia

\section{Research Article}

Keywords: algal blooms, algaecides, copper sulphate, hydrogen peroxide, decomposition

Posted Date: August 30th, 2021

DOI: https://doi.org/10.21203/rs.3.rs-741784/v1

License: (c) (1) This work is licensed under a Creative Commons Attribution 4.0 International License.

Read Full License

Version of Record: A version of this preprint was published at Environmental Science and Pollution Research on November 18th, 2021. See the published version at https://doi.org/10.1007/s11356-02117511-5. 


\section{Abstract}

The treatment and control of cyanobacterial blooms using copper-based algaecides in water reservoirs has historically been used, however, due to the adverse impact of copper on the environment, water authorities have been researching and studying new and innovative ways to control cyanobacterial blooms. Hydrogen peroxide has been investigated as an environmentally friendly alternative and this research aims to determine the impact of water quality on its effectiveness based on the decay characteristics in different water samples. Natural water samples from South Australian reservoirs were used to evaluate hydrogen peroxide decomposition and provide a better strategy for water operators in using it as an algaecide. Our experiments show the dependency of hydrogen peroxide decomposition not only on water quality but also on the initial hydrogen peroxide dose. A higher initial hydrogen peroxide dose can trigger the increase of $\mathrm{pH}$, leading to increased consumption of hydrogen peroxide. In addition, the hydrogen peroxide decomposition is significantly accelerated with the rise of copper concentration in water samples. Moreover, it is found that UV light can also affect the decomposition rate of hydrogen peroxide. The hydrogen peroxide decay is more significant under UV light for the samples with lower hydrogen peroxide concentrations. Our study also shows the impact of DOC on hydrogen peroxide decomposition is not substantial. The study also presents a modelling method to optimise hydrogen peroxide application based on water quality characteristics. Our findings can provide knowledge for the water industry to produce a suitable model which can be used to optimise the application of hydrogen peroxide for the control of cyanobacteria.

\section{Introduction}

Population increase, urban growth and expansion of agricultural practices have led to the increase of nutrient levels in the environment and waterways (Newcombe et al. 2012). This increase in nutrient concentration and increase in global temperatures, due to the climate change (Jančula \&Maršálek 2011, Newcombe et al. 2012), have had an obvious negative impact on the aquatic ecosystem, especially in the mass development of cyanobacteria in water resources (Jančula \&Maršálek 2011). Cyanobacteria in waterways has been the focus of many studies over recent decades given the environmental and health risks they pose on humans and other living species, such as livestock, wild mammals, birds and fishes (Dreyfus et al. 2016, García-Villada et al. 2004, Stewart et al. 2008). Humans can suffer from heart and kidney diseases, gastrointestinal irritation, liver failure or even death due to consumption of these toxins (Carmichael \&Boyer 2016, Fitzgerald et al. 1999, He et al. 2012, Westrick et al. 2010). This highlights the importance of having access to high quality and appropriately treated drinking water (Antoniou et al. 2013, Chow et al. 1999, Westrick et al. 2010, Xing et al. 2015). Moreover, cyanobacteria pose a challenge for water supply systems due to production of unpleasant taste and odour compounds (García-Villada et al. 2004, Lee et al. 2017). Consequently, this requires more intensive and costly treatment process to eliminate their presence (Hitzfeld et al. 2000).

To improve the effectiveness of treatment, a variety of options have been proposed to control cyanobacteria in the source waters. Stroom andKardinaal (2016) identified two major approaches to 
removing cyanobacteria, namely preventative and control. Preventative measures involve improvement of the chemical and biological health of the system and control encompasses direct actions to stop cyanobacteria proliferation. In reservoirs, one such direct control is chemical treatment using algaecides which have been widely utilised and extensively studied as a way of reducing cyanobacteria numbers prior to conventional drinking water processing (Antoniou et al. 2013, Chow et al. 1994, Fan et al. 2014, García-Villada et al. 2004). This includes the use of copper sulphate, copper chelates, aluminium sulphate, or potassium permanganate algaecides (Fan et al. 2014, García-Villada et al. 2004). Among these algaecides, the toxicity of copper sulphate on cyanobacteria cells and its effectiveness of algae elimination and cell density control has been widely studied and documented (Costas \&Lopez-Rodas 2006, Fan et al. 2013, García-Villada et al. 2004). Using copper sulphate is also economical and relatively safe for human health as well as easy to apply (Fan et al. 2013, García-Villada et al. 2004, Jančula \&Maršálek 2011). Copper sulphate is generally applied at the early stage of bloom formation. However, this treatment does not totally remove all cyanobacteria and repeat doses are required when cyanobacteria once again return (García-Villada et al. 2004). Furthermore, it has been speculated that the excessive treatment of algae, using copper sulphate, can develop cell resistance, which requires higher concentration and more frequent treatments (García-Villada et al. 2004, Kansole \&Lin 2017, Murray-Gulde et al. 2002). The excessive use of copper sulphate can also impact on the biotic and abiotic fresh water characteristics (Song \&Wang 2015) and has a serious ecological impact on non-target species (Greenfield et al. 2014, Jančula \&Maršálek 2011). For example, copper has a toxic effect on daphniids, and the fish, danio rerio (Closson \&Paul 2014, Jančula \&Maršálek 2011, Murray-Gulde et al. 2002). Additionally, copper can be transported from the water supply reservoir in a dissolved organic or inorganic form raising the risk of metal accumulation and toxicity in sediments (Fan et al. 2013, Jančula \&Maršálek 2011). The excessive and incorrect use of copper sulphate dosing has also been associated with hepatitis illness of children and adults in Palm Island in Queensland (Kansole \&Lin 2017, Prociv 2004).

There have been a number of studies examining the effectiveness of hydrogen peroxide $\left(\mathrm{H}_{2} \mathrm{O}_{2}\right)$, the active ingredient of sodium percarbonate (SP) when used as an algaecide. However, there is very little research on the impact of different water types with various chemical characteristics on residual $\mathrm{H}_{2} \mathrm{O}_{2}$ which acts as the algaecide. The current paper presents results from an investigation of the effects of different water chemistries on $\mathrm{H}_{2} \mathrm{O}_{2}$ decomposition and development of a models to estimate the $\mathrm{H}_{2} \mathrm{O}_{2}$ decomposition in water over time. This information will be valuable in understanding the activity of $\mathrm{H}_{2} \mathrm{O}_{2}$ as an algaecide in natural waters and help operators develop its use to control cyanobacterial blooms.

\section{Materials And Methods}

\subsection{Site selection and sample collection}

Experimental waters were sourced from three South Australian locations that have had a history of cyanobacterial blooms and include Happy Valley Reservoir, Torrens River, and Myponga Reservoir. Happy Valley Reservoir is located in Adelaide and supplies drinking water to over half a million people. The 
Torrens River is a recreational water course located near Adelaide's CBD. Myponga Reservoir is located about $60 \mathrm{~km}$ south of Adelaide and it is fed by the Myponga River and other smaller catchment streams, and provides about $5 \%$ of Adelaide's water supply.

Samples collected from these three sites were filtered through a $90 \mathrm{~mm}$ glass microfiber filter $\mathrm{Gf} / \mathrm{C}$ and kept in a refrigerator under $4^{\circ} \mathrm{C}$. All glassware and storage containers were washed three times with distilled water, followed by three washes with ultrapure deionised water (Milli-Q element, 18.2 M $\Omega$ ) before a final rinse with the reservoir water used in each experiment.

\subsection{Materials, reagents and solutions}

Sodium percarbonate (SP) stock solution was prepared by dissolving $18.382 \mathrm{~g}$ granulated SP (IXOM Operations Pty Ltd) in $1 \mathrm{~L}$ of Milli-Q water to give a final hydrogen peroxide concentration of $5 \mathrm{~g} / \mathrm{L}$. This stock solution was used to simulate the same method of $\mathrm{H}_{2} \mathrm{O}_{2}$ dosing in reservoir water. Copper sulphate solution was prepared by dissolving $9.82 \mathrm{~g}$ of $\mathrm{CuSO}_{4} \cdot 5 \mathrm{H}_{2} \mathrm{O}$ (AR, Chem-Supply) in a litre of Milli-Q water. Buffer stock to perform the $\mathrm{H}_{2} \mathrm{O}_{2}$ concentration measurement was prepared by mixing $18 \mathrm{~mL}$ of 0.5 $\mathrm{mol} / \mathrm{L} \mathrm{Na}_{2} \mathrm{HPO}_{4}$ and $82 \mathrm{~mL}$ of $0.5 \mathrm{~mol} / \mathrm{L} \mathrm{NaH}_{2} \mathrm{PO}_{4}$ to achieve $\mathrm{pH} 6$ in tested samples. N,N-diethyl-1,4phenlenediammonium sulphate (DPD) reagent was prepared by diluting $0.1 \mathrm{~g}$ of N,N-diethyl-1,4phenlenediammonium sulphate, Fluka, in $10 \mathrm{~mL}$ of $0.1 \mathrm{~N} \mathrm{H}_{2} \mathrm{SO}_{4}$. Horseradish peroxidase reagent was prepared by diluting $10 \mathrm{mg}$ of horseradish peroxidase, Type II, 181 purpurogallin units $/ \mathrm{mg}$, in $10 \mathrm{ml}$ of Milli-Q water (Drábková et al. 2007).

\section{3 $\mathrm{H}_{2} \mathrm{O}_{2}$ analysis / concentration determination}

The method used to measure the $\mathrm{H}_{2} \mathrm{O}_{2}$ concentration was adapted from Drábková et al. (2007), which was modified from Bader et al. (1988). $30 \% \mathrm{H}_{2} \mathrm{O}_{2}$ solution (AR, Chem-Supply) was used to create $\mathrm{H}_{2} \mathrm{O}_{2}$ standard solutions. Two $\mathrm{H}_{2} \mathrm{O}_{2}$ standard curves were prepared to determine the $\mathrm{H}_{2} \mathrm{O}_{2}$ at low and high concentration. The standard curve to determine low $\mathrm{H}_{2} \mathrm{O}_{2}$ concentration of less than $5 \mathrm{mg} / \mathrm{L}(0,0.056$, $0.113,0.226,0.564,1.13$ and $5.64 \mathrm{mg} / \mathrm{L}$ ) was prepared by mixing $16.6 \mu \mathrm{L}$ of $\mathrm{H}_{2} \mathrm{O}_{2}$ standard solution to 1 $\mathrm{L}$ of Milli-Q water, followed by multiple dilutions. The standard curve to measure high $\mathrm{H}_{2} \mathrm{O}_{2}$ concentration of more than $5 \mathrm{mg} / \mathrm{L}(0,0.11,0.57,1.13,2.27,3.4,6.8$ and $13.6 \mathrm{mg} / \mathrm{L})$ was prepared by mixing $1 \mathrm{~mL}$ of $\mathrm{H}_{2} \mathrm{O}_{2}$ to $1 \mathrm{~L}$ of Milli-Q water, then followed by multiple dilutions. Standard solutions were then analysed in Agilent Cary 60 UV-Vis spectrophotometer at $551.0 \mathrm{~nm}$.

For $\mathrm{H}_{2} \mathrm{O}_{2}$ concentrations up to $5 \mathrm{mg} / \mathrm{L}, 100 \mu \mathrm{L}$ of the buffer solution, $50 \mu \mathrm{L}$ of DPD reagent, and $50 \mu \mathrm{L}$ of HRP reagent and $900 \mu \mathrm{L}$ of the water sample were mixed in a polystyrene cuvette by inverting before immediately placing in UV-VIS spectrophotometer and measuring absorbance. Concentration was then determined from the corresponding standard curve. For $\mathrm{H}_{2} \mathrm{O}_{2}$ concentration greater than $5 \mathrm{mg} / \mathrm{L}, 100 \mu \mathrm{L}$ 
of the buffer solution, $850 \mu \mathrm{L}$ of Milli-Q water, $50 \mu \mathrm{L}$ of DPD reagent, and $50 \mu \mathrm{L}$ of HRP reagent was used. All measurements were made in triplicate.

\subsection{Investigate the effects of different parameters on $\mathrm{H}_{2} \mathrm{O}_{2}$ decomposition}

\section{a. The effects of different water types}

A $200 \mathrm{~mL}$ volume of either Milli-Q water or experimental water samples were dosed with 40, 200, 400 and $800 \mu \mathrm{L}$ of SP solution to achieve initial concentration of $1,5,10$ and $20 \mathrm{mg} / \mathrm{L} \mathrm{H}_{2} \mathrm{O}_{2}$. All samples were incubated (Thermoline Scientific TRIL-1175-2-SD) at $20^{\circ} \mathrm{C}$ in the dark over a 24-hour period to ensure the change in $\mathrm{H}_{2} \mathrm{O}_{2}$ concentration was not affected by changes in light or temperature. The water samples were collected at the time of initial dosage, and on every hour for a period of 7 hours to determine the $\mathrm{H}_{2} \mathrm{O}_{2}$ concentrations. At the same time, $\mathrm{pH}$ was measured using Oakton $\mathrm{pH}$ Meter (510 series) every hour for each water sample across all the four concentrations. Additionally, the $\mathrm{H}_{2} \mathrm{O}_{2}$ level was again measured 24 hours later from the initial dosage.

\section{b. Additional Control Experiments}

\section{i.The effect of UV light}

The experiment was conducted in Happy Valley reservoir water using the same method, concentrations and conditions as presented in 2.4a except in the presence of UV light. All samples were kept in the incubator under two UV lamps (Dermfix 3000 phototherapy 310-312 nm spectrum). $\mathrm{H}_{2} \mathrm{O}_{2}$ concentrations were measured at the time of initial dosage and on every hour for a period of 7 hours, with a final sample taken 24 hours after the initial dosage. $\mathrm{pH}$ was also determined over the same period.

\section{ii. The effect of copper sulphate under dark condition}

The experiment was carried out in Milli-Q water using same methodology presented in section 2.4a but replacing hydrogen peroxide with $0.5 \mathrm{mg} / \mathrm{L} \mathrm{Cu}^{2+}$. $\mathrm{pH}$ was determined as described previously.

\section{iii. The effect of DOC under dark condition}

The experiment was carried out in Milli-Q water as described in section 2.4a but with inclusion of dissolved organic carbon (DOC) extract as surrogate of natural organic matter (NOM) present in natural water samples. The DOC was added to the samples using the laboratory organic extract adopted from 
the Spent Brine of Mt Pleasant, South Australia, MIEX based Water Treatment Plant. $200 \mu \mathrm{L}$ of the organic compound was dosed into $200 \mathrm{~mL}$ samples to achieve $10 \mathrm{mg} / \mathrm{L} \mathrm{DOC}$ in all samples. $\mathrm{H}_{2} \mathrm{O}_{2}$ concentrations and $\mathrm{pH}$ were also determined using the same procedure as previously described.

\subsection{Data analysis and model development}

Experimental data was initially processed and analysed using Microsoft Excel. For further data analysis and model assessment, the three-column $\mathrm{H}_{2} \mathrm{O}_{2}$ concentration, dosage and time data were further analysed using TableCurve3D, Systat Software, Inc., to obtain the equation of best fit. TableCurve3D used the built-in equation types / equations to fit the experimental data and ranked against the $r^{2}$ value. The simple equation option was initially selected, if $r^{2}$ values were good, $>0.95$, then simple equation will be used to provide the best equation for the decay characteristic of each water sample, which were then used to establish an initial prediction model. By using the coefficients which were determined by the fitting procedure, the $\mathrm{H}_{2} \mathrm{O}_{2}$ decay behaviour can be established for each water source, thus, the CT (contact time $\mathrm{x}$ concentration) value can be determined.

\section{Results And Discussion}

\subsection{Characteristic of water sources}

The filtered water samples from three field sites were analysed to determine chemical characteristics. The results in Table 1 show that the total iron concentrations in filtered water samples were between 0.11 and $0.21 \mathrm{mg} / \mathrm{L}$, TKN was between 0.69 and $0.97 \mathrm{mg} / \mathrm{L}$, and $\mathrm{pH}$ between 7.6 and 8 from three field sites.

Torrens River and Happy Valley have similar total manganese levels of approximately $0.045 \mathrm{mg} / \mathrm{L}$ which is much higher than Myponga, with only $0.0017 \mathrm{mg} / \mathrm{L}$. Happy Valley has the lowest total phosphorus concentrations compared to others. 
Table 1

Measured water quality parameters for water samples collected from three field sites.

\begin{tabular}{llll} 
& Torrens River & Myponga & Happy Valley \\
\hline $\mathrm{pH}$ & 8.0 & 7.6 & 7.9 \\
\hline Iron-Total $(\mathrm{mg} / \mathrm{L})$ & 0.108 & 0.208 & 0.196 \\
\hline Manganese-Total $(\mathrm{mg} / \mathrm{L})$ & 0.045 & 0.002 & 0.049 \\
\hline Phosphorus-Total $(\mathrm{mg} / \mathrm{L})$ & 0.036 & 0.035 & $<0.003$ \\
\hline TKN $(\mathrm{mg} / \mathrm{L})$ & 0.97 & 0.83 & 0.69 \\
\hline Copper-Total $(\mathrm{mg} / \mathrm{L})$ & 0.003 & 0.025 & 0.435 \\
\hline DOC $(\mathrm{mg} / \mathrm{L})$ & 5.9 & 13.8 & 7.1
\end{tabular}

However, total copper and DOC concentrations showed large differences amongst the samples, Happy Valley water had a significantly higher total copper level compared to Torrens River (136 times higher) and Myponga Reservoir (17 times higher). Myponga Reservoir water had the highest DOC level of 13.8 $\mathrm{mg} / \mathrm{L}$ among the three water sources (Table 1 ). The rest of study will be concentrating on the impact of copper and DOC.

\subsection{The effects of different water types on $\mathrm{H}_{2} \mathrm{O}_{2}$ decomposition}

Figure 1 shows the effect of $\mathrm{H}_{2} \mathrm{O}_{2}$ dosages on $\mathrm{pH}$, two trends, low doses ( $1 \mathrm{mg} / \mathrm{L}$ and $5 \mathrm{mg} / \mathrm{L}$ ) and high doses $\left(10 \mathrm{mg} / \mathrm{L}\right.$ and $20 \mathrm{mg} / \mathrm{L}$ ), were observed. For low $\mathrm{H}_{2} \mathrm{O}_{2}$ dosages, an observable trend of $\mathrm{pH}$ decreased slightly after the addition of $\mathrm{H}_{2} \mathrm{O}_{2}$ then increased after 24 hours. For high dosages, $\mathrm{pH}$ initially increased then decreased after 24 hours. There is also another general trend of $\mathrm{pH}$ increased with the increasing $\mathrm{H}_{2} \mathrm{O}_{2}$ concentration. Milli-Q water has the highest $\mathrm{pH}$ increase (to $\mathrm{pH} 10$ ) after addition of $\mathrm{H}_{2} \mathrm{O}_{2}$ compared to the field water samples (increased to about $\mathrm{pH}$ 9), the final high $\mathrm{pH}$ in Milli-Q after addition of $\mathrm{H}_{2} \mathrm{O}_{2}$ is likely caused by the low buffering capacity of Milli-Q water. For the Myponga samples and Milli-Q water with low doses of $\mathrm{H}_{2} \mathrm{O}_{2}, \mathrm{pH}$ remained relatively constant over $24 \mathrm{~h}$ after addition of $\mathrm{H}_{2} \mathrm{O}_{2}$. The initial increase in $\mathrm{pH}$ after high $\mathrm{H}_{2} \mathrm{O}_{2}$ may explain the initial rapid loss of $\mathrm{H}_{2} \mathrm{O}_{2}$ concentration in high dose situations (will be discussed later in the manuscript).

Figure 2 presents the $\mathrm{H}_{2} \mathrm{O}_{2}$ decomposition (decay) for different water types over 24 hours. Our results show that there is no observable change in $\mathrm{H}_{2} \mathrm{O}_{2}$ concentration (decomposition) in Milli-Q water at different concentrations after 24 hours compared to other water types for low $\mathrm{H}_{2} \mathrm{O}_{2}$ concentration (1 $\mathrm{mg} / \mathrm{L}$ ). However, for high doses, a rapid initial drop in $\mathrm{H}_{2} \mathrm{O}_{2}$ concentration is observed (all four water types), this could be related to the initial increase in $\mathrm{pH}$ after $\mathrm{H}_{2} \mathrm{O}_{2}$ addition reported earlier. Torrens River samples showed a slow decomposition of $\mathrm{H}_{2} \mathrm{O}_{2}$. The $\mathrm{H}_{2} \mathrm{O}_{2}$ concentration decreased by $41 \%, 30 \%, 33 \%$, 
and $33 \%$ of the initial $\mathrm{H}_{2} \mathrm{O}_{2}$ concentrations of $1,5,10$, and $20 \mathrm{mg} / \mathrm{L}$, respectively after 24 hours. The results of Myponga Reservoir water samples presented a similar trend compared to Torrens water. The $\mathrm{H}_{2} \mathrm{O}_{2}$ concentrations in the samples reduced by $23 \%, 22 \%, 24 \%$ and $22 \%$ compared to initial concentrations of $1,5,10$, and $20 \mathrm{mg} / \mathrm{L}$, respectively. Conversely, the results of Happy Valley water samples showed a significant variation in $\mathrm{H}_{2} \mathrm{O}_{2}$ decomposition over the 24-hour period across all four concentrations. The results shown in Fig. 1 demonstrate a significant drop in the concentration with $100 \%$ loss of $\mathrm{H}_{2} \mathrm{O}_{2}$ at high $\mathrm{H}_{2} \mathrm{O}_{2}$ dosages ( 10 and $20 \mathrm{mg} / \mathrm{L}$ ), $95 \%$ was lost at $5 \mathrm{mg} / \mathrm{L}$ dosage while $67 \%$ was lost at $1 \mathrm{mg} / \mathrm{L}$ dosage after 24 hours. The results also showed a rapid decomposition in the early stage for the Happy Valley water samples where $24 \%$ was decomposed at $1 \mathrm{mg} / \mathrm{L}, 45 \%$ at $5 \mathrm{mg} / \mathrm{L}, 72 \%$ at $10 \mathrm{mg} / \mathrm{L}$ and $81 \%$ at $20 \mathrm{mg} / \mathrm{L}$ after the first hour. In general, for all water samples, the percentage lost has a direct relationship with the $\mathrm{H}_{2} \mathrm{O}_{2}$ dose i.e. higher the $\mathrm{H}_{2} \mathrm{O}_{2}$ dose the higher the percentage reduction. Studies showed that $\mathrm{H}_{2} \mathrm{O}_{2}$ was more stable in low and moderate $\mathrm{pH}$. However, when the $\mathrm{pH}$ continued to increase and reached alkalinity condition, it could lead to high consumption of $\mathrm{H}_{2} \mathrm{O}_{2}$ in solutions (Lee et al. 2013, Pędziwiatr 2018, Yazici \&Deveci 2010). From Fig. 1, we can see that higher initial dose of $\mathrm{H}_{2} \mathrm{O}_{2}$ triggered a significant change of $\mathrm{pH}$ after $\mathrm{H}_{2} \mathrm{O}_{2}$ was added. The increased $\mathrm{pH}$ can result into a rising rate of reaction for $\mathrm{H}_{2} \mathrm{O}_{2}$, leading to higher the percentage reduction of $\mathrm{H}_{2} \mathrm{O}_{2}$ (Fig. 2). From this result, higher $\mathrm{H}_{2} \mathrm{O}_{2}$ dose does not necessarily mean the $\mathrm{H}_{2} \mathrm{O}_{2}$ will perform better than lower $\mathrm{H}_{2} \mathrm{O}_{2}$ dose. If the system's $\mathrm{pH}$ increases significantly after initial does of $\mathrm{H}_{2} \mathrm{O}_{2}$, it could cause rapid consumption of $\mathrm{H}_{2} \mathrm{O}_{2}$, affecting its performance as an algaecide. In addition, over-application of $\mathrm{H}_{2} \mathrm{O}_{2}$ is not economic for the water authorities.

Furthermore, Happy Valley water showed a substantial and rapid loss of $\mathrm{H}_{2} \mathrm{O}_{2}$ concentration across all samples in comparison to Torrens River and Myponga Reservoir water. It was reported that the amount of copper was much higher in Happy Valley compared to Torrens River and Myponga Reservoir water and it is assumed that this is the reason for high $\mathrm{H}_{2} \mathrm{O}_{2}$ decomposition in Happy Valley water. To confirm whether the metal contents influenced the results, as assumed, further experiments were conducted using Milli-Q water with a similar concentration of copper sulphate found in Happy Valley water.

\subsection{The effect of copper sulphate on $\mathrm{H}_{2} \mathrm{O}_{2}$ decomposition}

The results of adding copper sulphate to the Milli-Q water samples were similar to Happy Valley water (Fig. 3). $1 \mathrm{mg} / \mathrm{L} \mathrm{H}_{2} \mathrm{O}_{2}$ test solutions showed a slower reduction with only $42 \%$ of $\mathrm{H}_{2} \mathrm{O}_{2}$ loss after 24 hours, while the $5 \mathrm{mg} / \mathrm{L} \mathrm{H}_{2} \mathrm{O}_{2}$ samples showed a $97 \%$ loss after the same duration. The samples with both 10 and $20 \mathrm{mg} / \mathrm{L} \mathrm{H}_{2} \mathrm{O}_{2}$ (high dosages) showed a rapid loss of $\mathrm{H}_{2} \mathrm{O}_{2}$ with $100 \%$ removal after 24 hours.

The results of the Milli-Q water mixed with similar copper concentration found in Happy Valley water samples of $0.5 \mathrm{mg} / \mathrm{L}$, showed very similar behaviour to the $\mathrm{H}_{2} \mathrm{O}_{2}$ decomposition of the Happy Valley water experiment conducted in the dark. This was in complete contrast to the Milli-Q water alone. These results suggest the rapid decay observed in the Happy Valley water samples was due to the presence of copper in the reservoir water. These results are consistent with the study of Akagawa andSuyama (2002), 
which indicated that $\mathrm{Cu}^{2+}$ was more effective than $\mathrm{Fe}^{3+}$ in catalysing the $\mathrm{H}_{2} \mathrm{O}_{2}$ and could generate hydroxyl radicals at a much higher rate than $\mathrm{Fe}^{3+}$. Others studies from Yazici andDeveci (2010) and Mlasi (2015) of $\mathrm{H}_{2} \mathrm{O}_{2}$ decomposition in the presence of copper also confirmed that the copper acts as a catalyst, which could accelerate $\mathrm{H}_{2} \mathrm{O}_{2}$ decay. Yazici andDeveci (2010) and Mlasi (2015) showed the $\mathrm{H}_{2} \mathrm{O}_{2}$ decomposition was also significantly accelerated as the amount of copper was increased. In addition, Lee et al. (2013) indicated that the catalytic decomposition of $\mathrm{H}_{2} \mathrm{O}_{2}$ by $\mathrm{Cu}^{2+}$ could be accelerated when $\mathrm{pH}$ increased. This is because the deprotonated form of $\mathrm{H}_{2} \mathrm{O}_{2}$ could act as the major electron-donor for the reduction of $\mathrm{Cu}^{2+}$. Therefore, the $\mathrm{pH}$ increase in solutions caused by higher initial $\mathrm{H}_{2} \mathrm{O}_{2}$ dose can also accelerate $\mathrm{H}_{2} \mathrm{O}_{2}$ decay under the presence of $\mathrm{Cu}^{2+}$.

Based on the experimental results, it has been confirmed that $\mathrm{H}_{2} \mathrm{O}_{2}$ decomposition is dependent on water quality, especially the amount of metals present. It was also confirmed that water types consisting of low metal contents, such as Torrens River and Myponga Reservoir water, can maintain $\mathrm{H}_{2} \mathrm{O}_{2}$ residual for over a 24-hour period. However, if metal content is high, such as observed in the Happy Valley samples, the algicidal activity of $\mathrm{H}_{2} \mathrm{O}_{2}$ could be impacted. In addition, the pH changes after the initial does of $\mathrm{H}_{2} \mathrm{O}_{2}$ could further affect the $\mathrm{H}_{2} \mathrm{O}_{2}$ decomposition with the presence of metals (Lee et al. 2013). Therefore, determining the optimum initial dose of $\mathrm{H}_{2} \mathrm{O}_{2}$ in the water bodies under laboratory condition is recommended before any large-scale application of $\mathrm{H}_{2} \mathrm{O}_{2}$ in the natural waters.

\subsection{The effect of UV light on $\mathrm{H}_{2} \mathrm{O}_{2}$ decomposition}

$\mathrm{H}_{2} \mathrm{O}_{2}$ combined in the presence of UV light for same sample conditions showed an increased decomposition rate compared to samples tested in the dark. $100 \%$ of the initial $\mathrm{H}_{2} \mathrm{O}_{2}$ concentration was decomposed in the higher concentration samples of 10 and $20 \mathrm{mg} / \mathrm{L}$ in an 8- and 4-hour period, respectively. This is compared to 24 and 6 hours of total $\mathrm{H}_{2} \mathrm{O}_{2}$ lost in the dark for the same concentration. In addition, the loss of the $\mathrm{H}_{2} \mathrm{O}_{2}$ in the first hour was greater than samples in the dark for 10 and $20 \mathrm{mg} / \mathrm{L}$ concentrations. The $\mathrm{H}_{2} \mathrm{O}_{2}$ was also $100 \%$ decomposed in all $\mathrm{H}_{2} \mathrm{O}_{2}$ doses after a 24-hour period. This showed a higher decomposition rate in comparison to the same water samples and concentrations when incubated in the dark. In Fig. 4, the side by side comparison of $\mathrm{H}_{2} \mathrm{O}_{2}$ decomposition in the dark and in the presence of UV light, it is more clearer in the low dose cases that the decay curve for samples in the dark has a higher corresponding $\mathrm{H}_{2} \mathrm{O}_{2}$ concentration than those with UV light.

Additionally, when $\mathrm{H}_{2} \mathrm{O}_{2}$ was combined with UV under the same conditions and concentrations, it was found that UV light affected the decomposition rate. This was especially evident with lower concentration samples, which maintained higher $\mathrm{H}_{2} \mathrm{O}_{2}$ residuals after a $24 \mathrm{~h}$ period compared to the same water tested in the dark. These results are consistent with the study of Drábková et al. (2007), which proved that low concentrations of $\mathrm{H}_{2} \mathrm{O}_{2}$ of 0.6 and $2.5 \mathrm{mg} / \mathrm{L}$ were decomposed in three hours of exposure to UV light. Drábková et al. (2007) argued that this proved the effect of UV on improving $\mathrm{H}_{2} \mathrm{O}_{2}$ toxicity. This was 
explained by the rapid decomposition in the presence of UV, which produced more hydroxyl radicals and enhanced the $\mathrm{H}_{2} \mathrm{O}_{2}$ toxicity on cyanobacteria cells.

\subsection{The effect of DOC on $\mathrm{H}_{2} \mathrm{O}_{2}$ decomposition}

To understand the impact of $\mathrm{NOM}$, the higher DOC concentration on $\mathrm{H}_{2} \mathrm{O}_{2}$ decomposition in Myponga Reservoir water (highest DOC concentration compared with the other samples), further experiments were conducted using Milli-Q water at similar concentration of the DOC found in Myponga Reservoir water. The Milli-Q water samples with added DOC did not show a significant loss of $\mathrm{H}_{2} \mathrm{O}_{2}$ after $24 \mathrm{~h}$, a similar result to Milli-Q water without added DOC concentrations when incubated in the dark (Fig. 5).

The results shown in Fig. 5 were in line with the study of Bissey et al. (2006), which found the same decomposition rate of $\mathrm{H}_{2} \mathrm{O}_{2}$ in natural soils with organic carbon content of $1.6 \%$ and $0.2 \%$. Huling et al. (2001) also confirmed that the decomposition of $\mathrm{H}_{2} \mathrm{O}_{2}$ was independent from organic matter and the decomposition occurs by catalytic reaction with metals rather than the organic component. However, Autin et al. (2013) explained that DOC can compete with cyanobacteria cells to react with the hydroxyl radicals produced by $\mathrm{H}_{2} \mathrm{O}_{2}$ decay. While the current study showed no impact of $\mathrm{DOC}$ on $\mathrm{H}_{2} \mathrm{O}_{2}$ decay the interaction of DOC with $\mathrm{H}_{2} \mathrm{O}_{2}$ in the presence of algal cells will need further investigation to understand any changes in algicidal activity in natural waters.

\subsection{Using curve fitting technique to model decay in the presence of copper}

From our findings, the cause of decay was mainly due to the presence of copper in the water. In this section, a curve fitting technique was applied to understand the decay behaviour of $\mathrm{H}_{2} \mathrm{O}_{2}$ in the presence of copper. The copper concentrations of Torrens River, Myponga Reservoir and Happy Valley water samples determined by copper analysis showed the results are in the order of magnitude difference of $\mathrm{ug} / \mathrm{L}, 10 \mathrm{ug} / \mathrm{L}$ and $100 \mathrm{ug} / \mathrm{L}$ range, respectively. The autofit function in TableCurve3D was used to get the best fit equation i.e. highest $r^{2}$ value. As explained earlier in the Materials and methods section, TableCurve3D used it's equation library to find the best fit equations and ranked them based on the $r^{2}$ value from high to low. For the Happy Valley water decay data, the top ranked equation is Eq. 302461513 : $z^{-1}=a+b x+c / y, r^{2}=0.97, z$ is $\mathrm{H}_{2} \mathrm{O}_{2}$ concentration in $\mathrm{mg} / \mathrm{L}, \mathrm{x}$ is time and $\mathrm{y}$ is $\mathrm{H}_{2} \mathrm{O}_{2}$ dose. The same fitting procedure was conducted for Myponga and Torrens River decay data sets, Eq. $151232881 \ln z=a+b e^{-x}$ $+c \ln y$ is the top ranked equation for both waters, $r^{2}=1.00$ and 0.99 for Myponga and Torrens River waters, respectively. Despite the order of magnitude difference for Happy Valley, Myponga and Torrens River, the same equation / equation family was listed as the best fit for the decay curves for Torrens River and Myponga, while Happy Valley has a different equation. This indicates that the impact of copper on $\mathrm{H}_{2} \mathrm{O}_{2}$ decay may only occur when a threshold level is reached. Both the copper concentrations in Myponga $(0.025 \mathrm{mg} / \mathrm{L} \mathrm{Cu})$ and Torrens $(0.003 \mathrm{mg} / \mathrm{L} \mathrm{Cu})$ would be below the threshold level thus the 
same best fit equation was found to represent the decay characteristics. While in Happy Valley the copper concentration is in $100 \mathrm{ug} / \mathrm{L}$ range and a different equation was found to represent the decay characteristics.

Table 3

Coefficients for the best curve fitting equation for Happy Valley, Myponga and Torrens River.

\begin{tabular}{llll} 
& Equation & $\mathrm{r}^{2}$ & Coefficients \\
\hline Happy Valley & $\mathrm{z}^{-1}=\mathrm{a}+\mathrm{bx}+\mathrm{c} / \mathrm{y}$ & 0.97 & $\mathrm{a}=-0.004, \mathrm{~b}=0.195, \mathrm{c}=1.071$ \\
\hline Myponga & $\ln \mathrm{z}=\mathrm{a}+\mathrm{b} \mathrm{e}^{-\mathrm{x}}+\mathrm{c} \ln \mathrm{y}$ & 1.00 & $\mathrm{a}=0.296, \mathrm{~b}=0.177, \mathrm{c}=1.020$ \\
\hline Torrens River & $\ln \mathrm{z}=\mathrm{a}+\mathrm{b} \mathrm{e}^{-\mathrm{x}}+\mathrm{c} \ln \mathrm{y}$ & 0.99 & $\mathrm{a}=0.355, \mathrm{~b}=0.267, \mathrm{c}=0.998$
\end{tabular}

Additionally, the coefficients, a, b, c values, presented in Table 3 can be used determine the $\mathrm{H}_{2} \mathrm{O}_{2}$ concentration for a particular dose at a particular time to estimate the efficiency. The equation developed by this research can be used as a model to estimate the required initial $\mathrm{H}_{2} \mathrm{O}_{2}$ dose for a set contact time in a particular water type. Furthermore, a CT value can also be determined.

\section{Conclusion}

This study investigated hydrogen peroxide decomposition in different natural water samples from South Australia, including two reservoirs and a river, to provide a better understanding of its activity as an algaecide. Cyanobacteria is an ongoing problem in water reservoirs, wastewater systems, and recreational waters in South Australia (Baker \&Humpage 1994). During the period of late 1990s until 2011, Torrens River was closed for some time during summer periods because of algae growth, which formed scums, produced unpleasant odours, and released toxins that could impact both the human and the natural environment. Copper sulphate has been used in South Australia for more than 50 years to control algal growth in some of the state's reservoirs. However, its harmful impact on the environment and increasing cost of the chemical, has driven our local water utility, SA Water, to identify and develop innovative alternative algal control methods. One of the potential alternatives, sodium percarbonate, is considered a more environmentally friendly option than copper sulphate.

The results from our research have shown that water quality and chemistry can play an important role in hydrogen peroxide decomposition in water and in turn its toxicity to cyanobacteria. It is evident that water components, especially metals, such as ambient level of copper in the reservoir, can impact the rate of decomposition of $\mathrm{H}_{2} \mathrm{O}_{2}$ in natural waters. Additionally, the $\mathrm{pH}$ changes related to the initial $\mathrm{H}_{2} \mathrm{O}_{2}$ does can affect the rate of decomposition of $\mathrm{H}_{2} \mathrm{O}_{2}$ in water. Moreover, this work highlights the effect of UV light availability on the decomposition of $\mathrm{H}_{2} \mathrm{O}_{2}$. The knowledge gained from this research will be important for constructing a model explaining the interactions of hydrogen peroxide in natural systems and developing 
formulae to help reservoir operators determine the required algaecide dose for removal of problem cyanobacteria.

\section{Declarations}

\section{Acknowledgments}

The authors would like to thank UniSA STEM and SA Water to support Maximus Ghaly's Master study.

\section{Ethical Approval}

Not applicable.

\section{Consent to Participate}

Not applicable.

\section{Consent to Publish}

Not applicable.

\section{Authors Contributions}

Jianyin Huang: experimental design, data analysis, manuscript writing and supervision. Maximus Ghaly: experiment, data analysis and manuscript writing. Peter Hobson: experimental design, manuscript writing and supervision.Christopher W.K. Chow: experimental design, data analysis, manuscript writing and supervision.

\section{Funding}

Not applicable.

\section{Competing Interests}

The authors declare no competing interests.

\section{Availability of data and materials}


Not applicable.

\section{References}

1. Akagawa M, Suyama K (2002) Oxidative deamination by hydrogen peroxide in the presence of metals. Free Radic Res 36:13-22

2. Antoniou MG, De La Cruz AA, Pelaez MA, Han C, He X, Dionysiou DD, Song W, O'Shea KE, Ho L, Newcombe G (2013) Practices that prevent the formation of cyanobacterial blooms in water resources and remove cyanotoxins during physical treatment of drinking water

3. Autin O, Hart J, Jarvis P, MacAdam J, Parsons SA, Jefferson B (2013) The impact of background organic matter and alkalinity on the degradation of the pesticide metaldehyde by two advanced oxidation processes: UV/H2O2 and UV/TiO2. Water Res 47:2041-2049

4. Bader H, Sturzenegger V, Hoigne J (1988) Photometric method for the determination of low concentrations of hydrogen peroxide by the peroxidase catalyzed oxidation of N, N-diethyl-pphenylenediamine (DPD). Water Res 22:1109-1115

5. Baker P, Humpage A (1994) Toxicity associated with commonly occurring cyanobacteria in surface waters of the Murray-Darling Basin, Australia. Marine Freshwater Research 45:773-786

6. Bissey LL, Smith JL, Watts RJ (2006) Soil organic matter-hydrogen peroxide dynamics in the treatment of contaminated soils and groundwater using catalyzed $\mathrm{H} 2 \mathrm{O} 2$ propagations (modified Fenton's reagent). Water Res 40:2477-2484

7. Carmichael WW, Boyer GL (2016) Health impacts from cyanobacteria harmful algae blooms: Implications for the North American Great Lakes. Harmful algae 54:194-212

8. Chow CW, Davey DE, Mulcahy DE (1994) On-site monitoring of total copper by anodic stripping voltammetry, during algicide dosing of a reservoir. Anal Lett 27:113-130

9. Chow CW, Drikas M, House J, Burch MD, Velzeboer RM (1999) The impact of conventional water treatment processes on cells of the cyanobacterium Microcystis aeruginosa. Water Res 33:32533262

10. Closson K, Paul E (2014) Comparison of the toxicity of two chelated copper algaecides and copper sulfate to non-target fish. Bull Environ Contam Toxicol 93:660-665

11. Costas E, Lopez-Rodas V (2006) Copper sulphate and DCMU-herbicide treatments increase asymmetry between sister cells in the toxic cyanobacteria Microcystis aeruginosa: implications for detecting environmental stress. Water Res 40:2447-2451

12. Drábková $M$, Admiraal W, Maršálek $B$ (2007) Combined exposure to hydrogen peroxide and light selective effects on cyanobacteria, green algae, and diatoms. Environ Sci Technol 41:309-314

13. Dreyfus J, Monrolin Y, Pestana CJ, Reeve PJ, Sawade E, Newton K, Ho L, Chow CW, Newcombe G (2016) Identification and assessment of water quality risks associated with sludge supernatant recycling in the presence of cyanobacteria. Journal of Water Supply: Research Technology-AQUA 65:441-452 
14. Fan J, Ho L, Hobson P, Brookes J (2013) Evaluating the effectiveness of copper sulphate, chlorine, potassium permanganate, hydrogen peroxide and ozone on cyanobacterial cell integrity. Water Res 47:5153-5164

15. Fan J, Ho L, Hobson P, Daly R, Brookes J (2014) Application of various oxidants for cyanobacteria control and cyanotoxin removal in wastewater treatment. J Environ Eng 140:04014022

16. Fitzgerald DJ, Cunliffe DA, Burch MD (1999) Development of health alerts for cyanobacteria and related toxins in drinking water in South Australia. Environmental Toxicology: An International Journal 14:203-209

17. García-Villada L, Rico M, Altamirano Ma, Sánchez-Martín L, López-Rodas V, Costas E (2004) Occurrence of copper resistant mutants in the toxic cyanobacteria Microcystis aeruginosa: characterisation and future implications in the use of copper sulphate as algaecide. Water Res 38:2207-2213

18. Greenfield DI, Duquette A, Goodson A, Keppler CJ, Williams SH, Brock LM, Stackley KD, White D, Wilde SB (2014) The effects of three chemical algaecides on cell numbers and toxin content of the cyanobacteria Microcystis aeruginosa and Anabaenopsis sp. Environmental management 54:11101120

19. He X, Pelaez M, Westrick JA, O'Shea KE, Hiskia A, Triantis T, Kaloudis T, Stefan MI, Armah A, Dionysiou DD (2012) Efficient removal of microcystin-LR by UV-C/H2O2 in synthetic and natural water samples. Water Res 46:1501-1510

20. Hitzfeld BC, Höger SJ, Dietrich DR (2000) Cyanobacterial toxins: removal during drinking water treatment, and human risk assessment. Environmental health perspectives 108:113

21. Huling SG, Arnold RG, Sierka RA, Miller MR (2001) Influence of peat on Fenton oxidation. Water Res 35:1687-1694

22. Jančula D, Maršálek B (2011) Critical review of actually available chemical compounds for prevention and management of cyanobacterial blooms. Chemosphere 85:1415-1422

23. Kansole MM, Lin T-F (2017) Impacts of Hydrogen Peroxide and Copper Sulfate on the Control of Microcystis aeruginosa and MC-LR and the Inhibition of MC-LR Degrading Bacterium Bacillus sp. Water 9:255

24. Lee H, Lee H-J, Sedlak DL, Lee C (2013) pH-Dependent reactivity of oxidants formed by iron and copper-catalyzed decomposition of hydrogen peroxide. Chemosphere 92:652-658

25. Lee J, Rai PK, Jeon YJ, Kim K-H, Kwon EE (2017) The role of algae and cyanobacteria in the production and release of odorants in water. Environmental pollution 227:252-262

26. Mlasi B (2015) The decomposition of hydrogen peroxide in acidic copper sulfate solutions

27. Murray-Gulde C, Heatley J, Schwartzman A, Rodgers J Jr (2002) Algicidal effectiveness of clearigate, cutrine-plus, and copper sulfate and margins of safety associated with their use. Arch Environ Contam Toxicol 43:19-27

28. Newcombe G, Chorus I, Falconer I, Lin T-F (2012) Cyanobacteria: impacts of climate change on occurrence, toxicity and water quality management. Water Res 46:1347 
29. Pędziwiatr P (2018) Decomposition of hydrogen peroxide-kinetics and review of chosen catalysts. Acta Innovations, 45-52

30. Prociv P (2004) Algal toxins or copper poisoning-revisiting the Palm Island" epidemic". Med J Aust 181:344

31. Song L-Y, Wang Y-Q (2015) Investigation of microbial community structure of a shallow lake after one season copper sulfate algaecide treatment. Microbiological research 170:105-113

32. Stewart I, Seawright AA, Shaw GR (2008) Cyanobacterial poisoning in livestock, wild mammals and birds-an overview. In: Cyanobacterial harmful algal blooms: state of the science and research needs. Springer, pp 613-637

33. Stroom JM, Kardinaal WEA (2016) How to combat cyanobacterial blooms: strategy toward preventive lake restoration and reactive control measures. Aquat Ecol 50:541-576

34. Westrick JA, Szlag DC, Southwell BJ, Sinclair J (2010) A review of cyanobacteria and cyanotoxins removal/inactivation in drinking water treatment. Analytical bioanalytical chemistry 397:1705-1714

35. Xing L, Chow CW, Zuo J, Wang D, Fabris R, van Leeuwen J, Drikas M (2015) Impact of extracted algogenic organic matter on coagulation performance. Water Science Technology: Water Supply 15:617-624

36. Yazici E, Deveci H (2010) Factors affecting decomposition of hydrogen peroxide, Proceedings of the XIlth international mineral processing symposium. Mining Engineering Department, Hacettepe University, pp. 609-616

\section{Tables}

Table 2 is not available with this version.

\section{Figures}




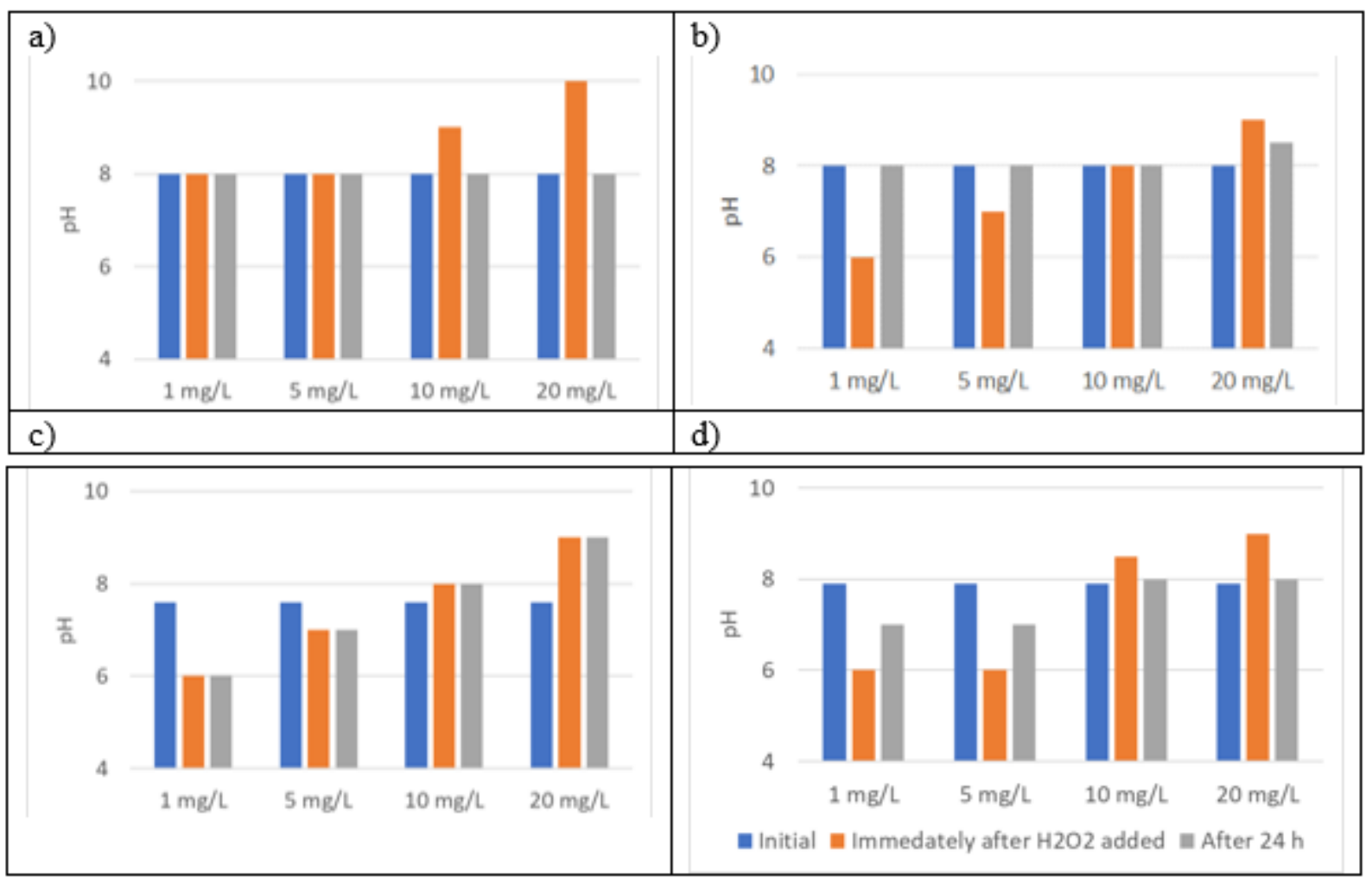

Figure 1

$\mathrm{pH}$ changes in the water samples at different dosages, $1 \mathrm{mg} / \mathrm{L}, 5 \mathrm{mg} / \mathrm{L}, 10 \mathrm{mg} / \mathrm{L}$ and $20 \mathrm{mg} / \mathrm{L}$, of H2O2 over $24 \mathrm{~h}$ in a) Milli-Q, b) Torrens River, c) Myponga and d) Happy Valley.

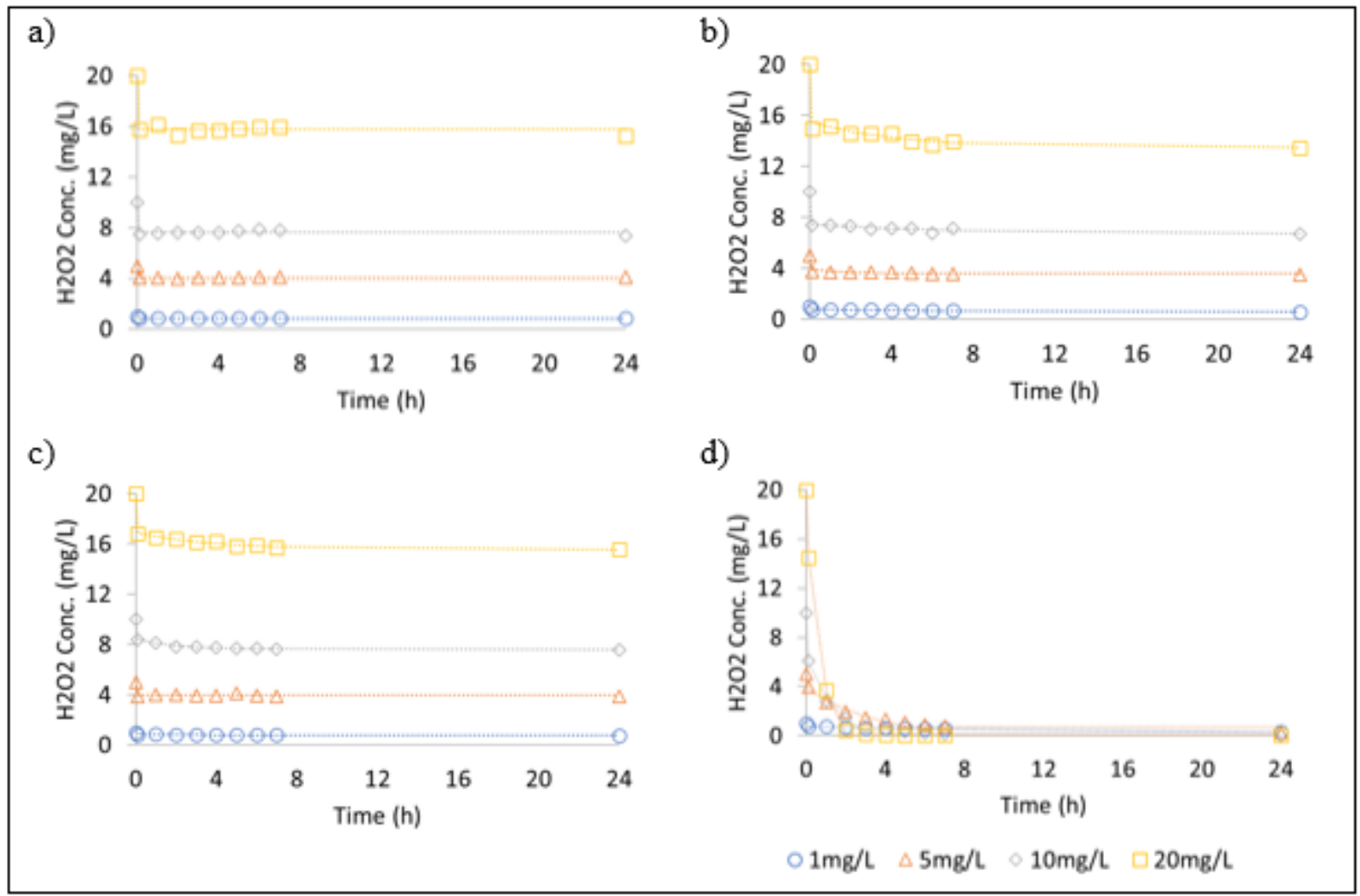


Figure 2

The $\mathrm{H} 2 \mathrm{O} 2$ decomposition (decay) in different water types, a) Milli-Q, b) Torrens River, c) Myponga and d) Happy Valley with different $\mathrm{H} 2 \mathrm{O} 2$ dosages, $1 \mathrm{mg} / \mathrm{L}, 5 \mathrm{mg} / \mathrm{L}, 10 \mathrm{mg} / \mathrm{L}$ and $20 \mathrm{mg} / \mathrm{L}$. Measurements were done in triplicates, standard deviations were determined to be within $5 \%$ error, for clarity of the figure, error bars were not shown.

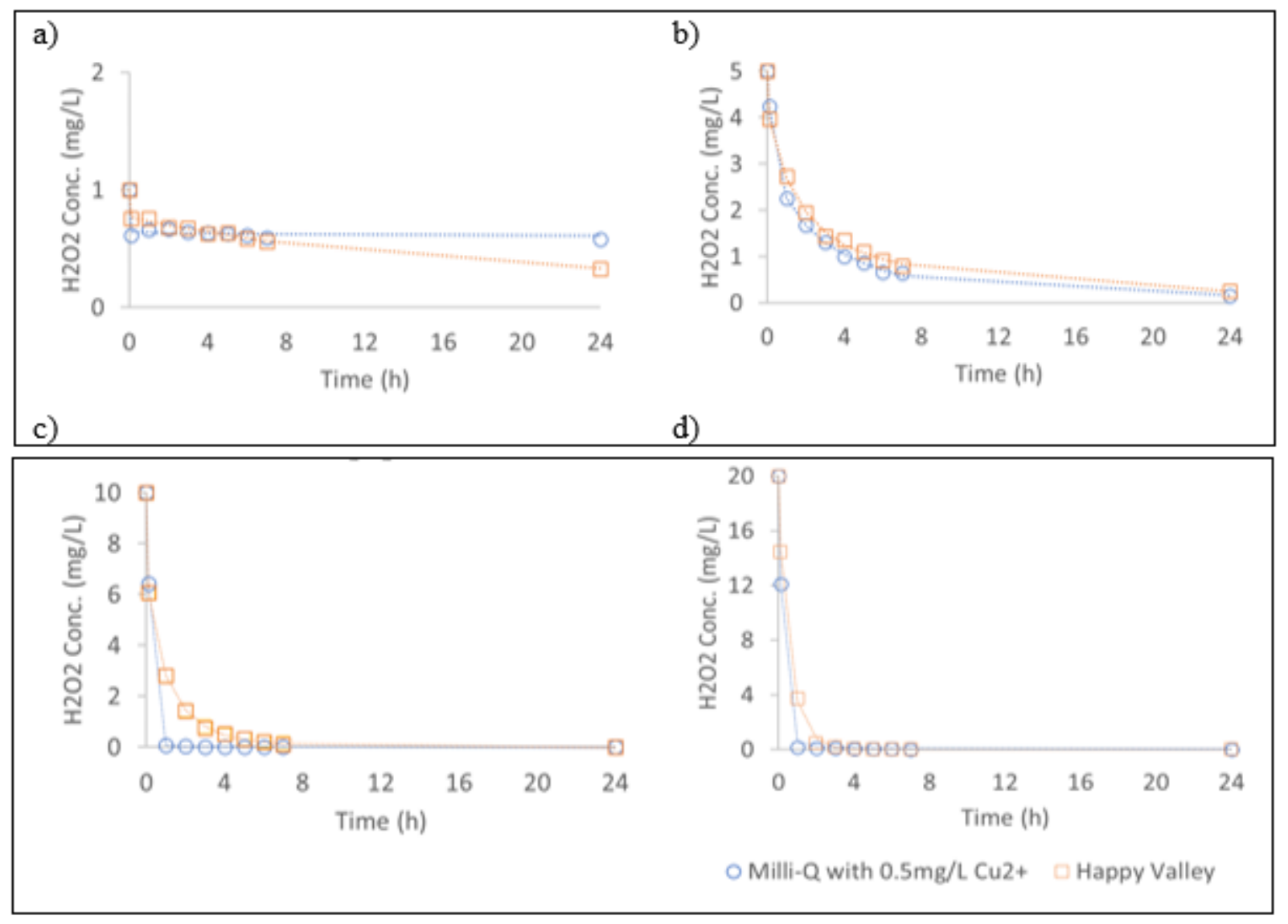

\section{Figure 3}

The H2O2 decomposition in Milli-Q water with $0.5 \mathrm{mg} / \mathrm{L}$ of Cu2+ and Happy Valley water dosed by various $\mathrm{H} 2 \mathrm{O} 2$ dosages, a) $1 \mathrm{mg} / \mathrm{L}$, b) $5 \mathrm{mg} / \mathrm{L}$, c) $10 \mathrm{mg} / \mathrm{L}$ and d) $20 \mathrm{mg} / \mathrm{L}$. Measurements were done in triplicates, standard deviations were determined to be within $5 \%$ error, for clarity of the figure, error bars were not shown. 


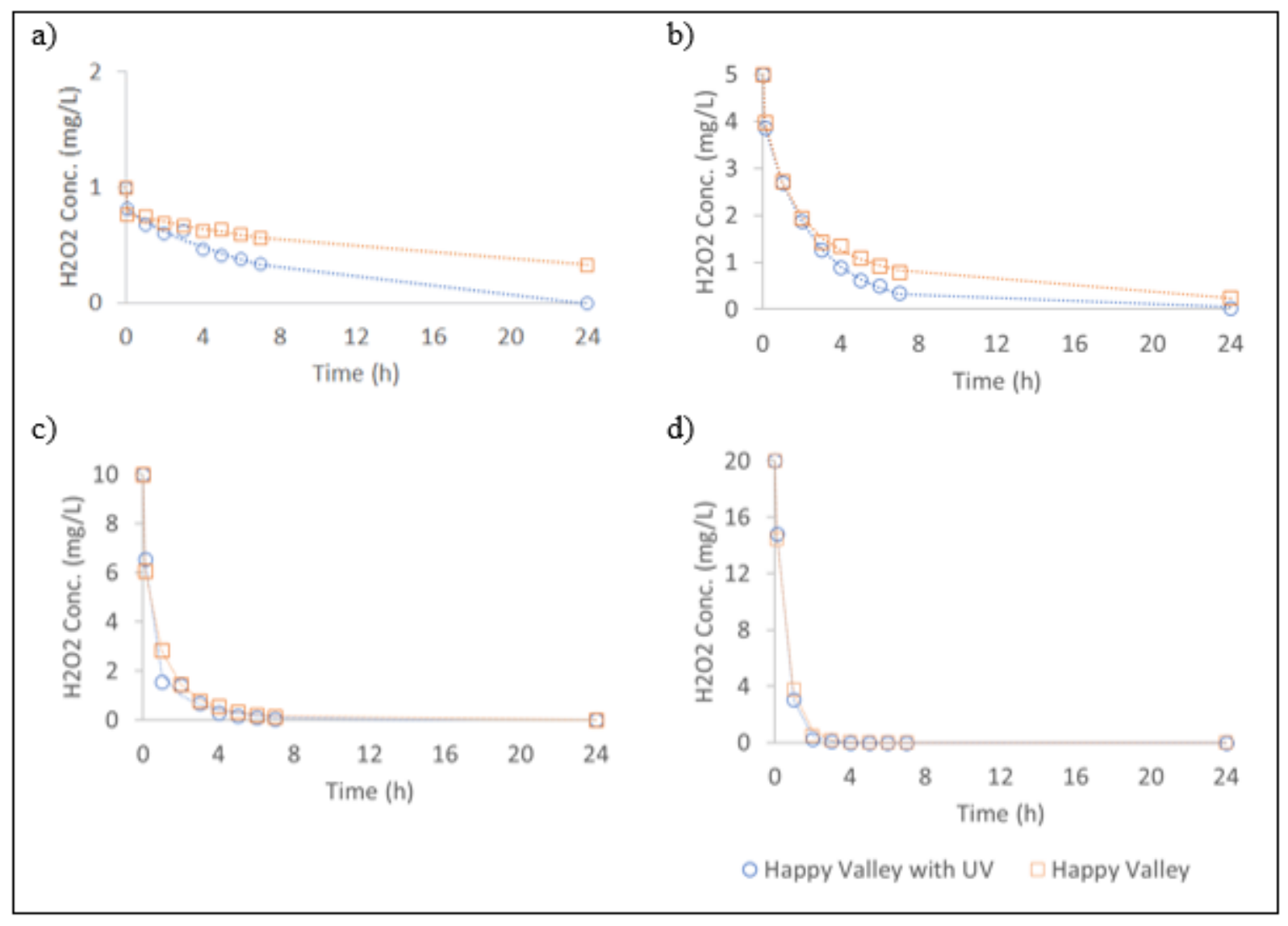

Figure 4

$\mathrm{H} 2 \mathrm{O} 2$ decomposition curve for Happy Valley water with UV light and in the dark with various $\mathrm{H} 2 \mathrm{O} 2$ dosages, a) $1 \mathrm{mg} / \mathrm{L}$, b) $5 \mathrm{mg} / \mathrm{L}$, c) $10 \mathrm{mg} / \mathrm{L}$ and d) $20 \mathrm{mg} / \mathrm{L}$. Measurements were done in triplicates, standard deviations were determined to be within $5 \%$ error, for clarity of the figure, error bars were not shown. 


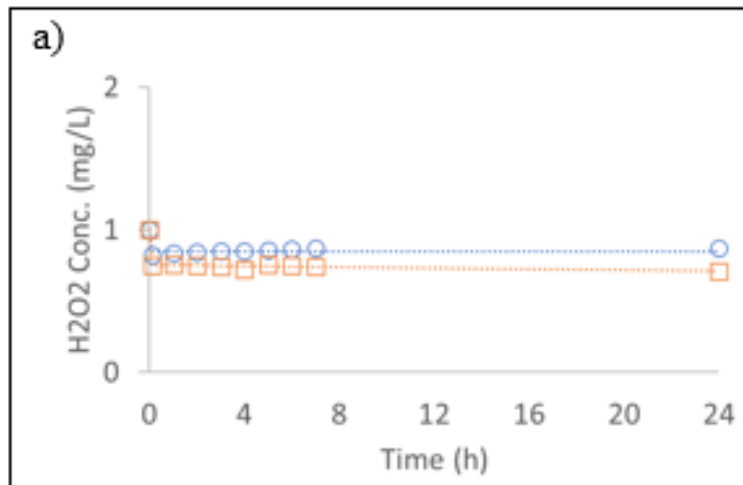

b)

c)

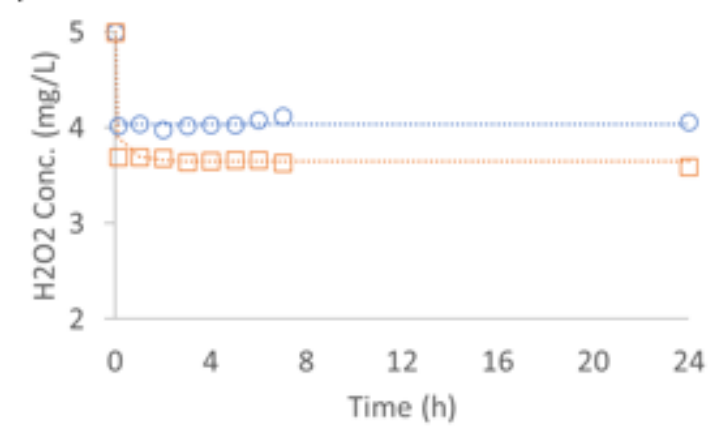

d)
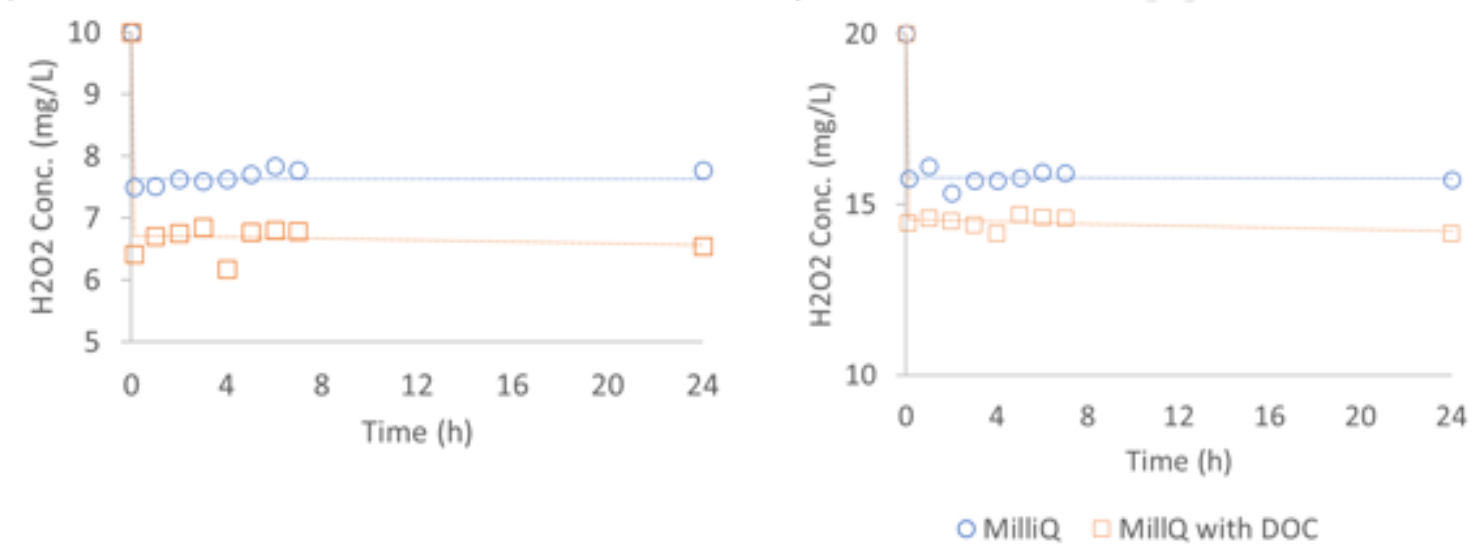

Figure 5

H2O2 decomposition curve for Mill-Q and Mill-Q with added DOC with various H2O2 dosages, a) $1 \mathrm{mg} / \mathrm{L}$, b) $5 \mathrm{mg} / \mathrm{L}$, c) $10 \mathrm{mg} / \mathrm{L}$ and d) $20 \mathrm{mg} / \mathrm{L}$. Measurements were done in triplicates, standard deviations were determined to be within $5 \%$ error, for clarity of the figure, error bars were not shown. 